УДК 633.15:631.5

(C) 2016

Котченко М. В., кандидат сільськогосподарських наук,

Кирсанова Г. В., кандидат сільськогосподарських наук,

Пугач А. М., кандидат технічних наук, доктор наук з державного управління, Пугач А. В., аспірант

(науковий керівник - доктор наук з державного управління І. П. Приходько)

Дніпропетровський державний аграрно-економічний університет

\title{
ПРОДУКТИВНІСТЬ РІЗНОСТИГЛИХ ГІБРИДІВ КУКУРУДЗИ В УМОВАХ ПІВНІЧНОГО СТЕПУ УКРАЇНИ
}

\section{Рецензент - доктор сільськогосподарських наук I. І. Ярчук}

\begin{abstract}
У статті представлено результати наукових досліджень щзодо росту та розвитку рослин гібридів кукурудзи різних груп стиглості. Наведено дані щодо формування площчі листкової поверхні, елементів структури урожайності, передзбиральної вологості зерна, урожайності основної продукиії, економічної ефективності вирощування гібридів кукурудзи. Встановлено, щзо найбільи адаптованим для даних умов вирощування виявився середньостиглий гібрид НК Леморо, шо формував урожайність зерна на рівні $8,67 \mathrm{~m} / \mathrm{za}$.
\end{abstract}

Ключові слова: кукурудза, гібриди, урожайність, вологість зерна, економічна ефективHicmb.

Постановка проблеми. Сучасні гібриди кукурудзи різних біотипів значно різняться за морфобіологічними ознаками, властивостями та вимогами до умов вирощування. У зв'язку з цим для виявлення потенціальної продуктивності кожного конкретного гібриду необхідно створювати сприятливі умови для росту і розвитку рослин, які в свою чергу обумовлюються агротехнічними заходами і природно-кліматичними ресурсами.

Аналіз останніх досліджень і публікацій, у яких започатковано розв'язання проблеми. Експериментальні дані свідчать, що урожайність кукурудзи в меншій мірі залежить від продуктивності гібрида, а в більшій - від технології і умов його вирощування $[1,4,5]$. Щоб отримати високий і стабільний урожай, необхідно здійснити відбір кращих гібридів, адаптованих до умов конкретної грунтово-кліматичної зони та створити відповідний їх потребам агротехнічний фон. Результати досліджень, які були проведені в різних грунтово-кліматичних умовах України, і передовий досвід вирощування кукурудзи в агроформуваннях свідчать про можливість одержувати високі та стабільні врожаї зерна кукурудзи в разі виконання елементів технології - 4,0-6,0 т/га в незрошуваних умовах і 10,0-12,0 т/га - у випадку зрошення [2, 4]. Серед новостворених біотипів кукурудзи існують форми інтенсивного типу, які вибагливі до умов зовнішнього середовища $\mathrm{i}$ рівня агротехніки, а також гібриди, які мають понижену реакцію на зміну прийомів вирощування, що обумовлює помітний економічний ефект від їх виробництва [3-5]. У зв'язку з цим значної актуальності набувають дослідження 3 визначення найбільш адаптованих форм кукурудзи, придатних для вирощування за подібними технологічними схемами в конкретних грунтовокліматичних умовах.

Метою проведення нашої роботи було дослідити особливості росту, розвитку та формування урожайності гібридів кукурудзи НК Сімба (середньоранній, ФАО 270), НК Леморо (середньостиглий, ФАО 310) та Сіско (середньопізній, ФАО 400), занесених до Державного реєстру сортів рослин придатних для поширення в Україні. Також визначити ті, що в умовах Північного Степу дають найвищий економічний ефект від їх виробництва.

Матеріали і методи досліджень. Дослідження проводили протягом 2014-2015 рр. Грунтовий покрив дослідних ділянок представлений чорноземами звичайними малогумусними середньопотужними на лесі. Вміст гумусу в орному шарі повнопрофільних чорноземів змінюється в межах (3,7-4,1\%). Вміст валового азоту становить 15-20 мг/кг (за К'єльдалем), рухомого фосфору міститься 100-150 мг/кг, обмінного калію - 100120 мг/кг грунту (за Чириковим). Облікова площа ділянок становила $50,4 \mathrm{~m}^{2}$, повторення - триразове. Попередник кукурудзи - пшениця озима. Після збирання попередника проводили лущення стерні дисковими лущильниками на глибину 6-8 cм, повторне - після проростання бур'янів, що сприяло ефективній боротьбі з бур'янами та накопиченню вологи у грунті. Оранку проводили в останніх числах вересня на глибину 25-27 см. 
Технологія вирощування кукурудзи, за виключенням поставлених на вивчення питань, була загальноприйнятою для умов Північного Степу України.

Під час проведення досліджень використовували наступні методи: вимірювально-розрахунковий у випадку біометричного аналізу рослин; ваговий - під час визначення вологості зерна; візуальний - під час встановлення фаз росту і розвитку рослин; математичної статистики - під час планування досліджень, оцінки достовірності одержаних результатів; розрахунково-порівняльний - для оцінки економічної ефективності вирощування кукурудзи.

Результати досліджень. За результатами досліджень встановлено, що площа листкової поверхні посівів поставлених на вивчення гібридів найбільшою була у фазі викидання волоті. Так, у гібрида Сіско показник площі листкової поверхні був найвищим і становив 42,1 тис. м $^{2} /$ га, у гібрида НК Леморо - 35,7 тис. м $^{2} /$ га, у гібрида Сімба $-32,8$ тис. м $^{2} /$ га. Мінімального значення даний показник усіх гібридів набував у фазу воскової стиглості. Так, площа листкової поверхні у гібрида НК Леморо становила 23,4 тис. м ${ }^{2} /$ га, у гібрида Сіско - 25,1 тис. м $^{2} /$ га, у гібрида Сімба 21,8 тис. $\mathrm{m}^{2} /$ га (табл. 1$)$.

Висота рослин досліджуваних гібридів куку- рудзи також змінювалась залежно від гідротермічних умов року, біологічних особливостей та умов вирощування.

Так, у середньому за роки досліджень найбільшою висота рослин зафіксована у гібрида Сіско - 245 см. Дещо нижчими показники були у НК Леморо та НК Сімба.

У фазу воскової стиглості висота рослин не залежно від гібриду дещо знижувалась і коливалась у межах 233-241 см, що пояснюється природним всиханням рослини та зменшенням вегетативної маси.

Відомо, що максимальну урожайність зерна кукурудзи можна одержати за оптимального співвідношення елементів індивідуальної продуктивності рослин.

Показниками, що формують індивідуальну продуктивність рослин кукурудзи $є$ кількість качанів на 100 рослинах, маса зерна 3 одного качана та маса тисячі насінин.

За результатами наших досліджень встановлено, що найвищу кількість качанів на 100 рослинах, а відповідно і на 1 га, сформував середньостиглий гібрид НК Леморо. Дещо нижчим цей показник був у середньораннього гібрида НК Сімба та середньопізнього Сіско - на 3,8 \% та $5,6 \%$ відповідно.

1. Динаміка площі листкової поверхні гібридів кукурудзи (тис. м²), середнє за 2014-2015 рр.

\begin{tabular}{|c|c|c|c|c|c|c|}
\hline \multirow[b]{3}{*}{ Гібрид } & \multicolumn{6}{|c|}{ Фаза розвитку } \\
\hline & \multicolumn{3}{|c|}{ викидання волоті } & \multicolumn{3}{|c|}{ воскова стиглість } \\
\hline & площа & $\begin{array}{c}\text { кількість листків } \\
\text { на } \\
1 \text { рослину }\end{array}$ & висота, см & площа & $\begin{array}{c}\text { кількість листків } \\
\text { на } 1 \text { рослину }\end{array}$ & висота, см \\
\hline НК Сімба & 32,8 & 12,4 & 234 & 21,8 & 11,3 & 233 \\
\hline НК Леморо & 35,7 & 12,8 & 240 & 23,4 & 11,7 & 237 \\
\hline Сіско & 42,1 & 14,1 & 245 & 25,1 & 12,3 & 241 \\
\hline
\end{tabular}

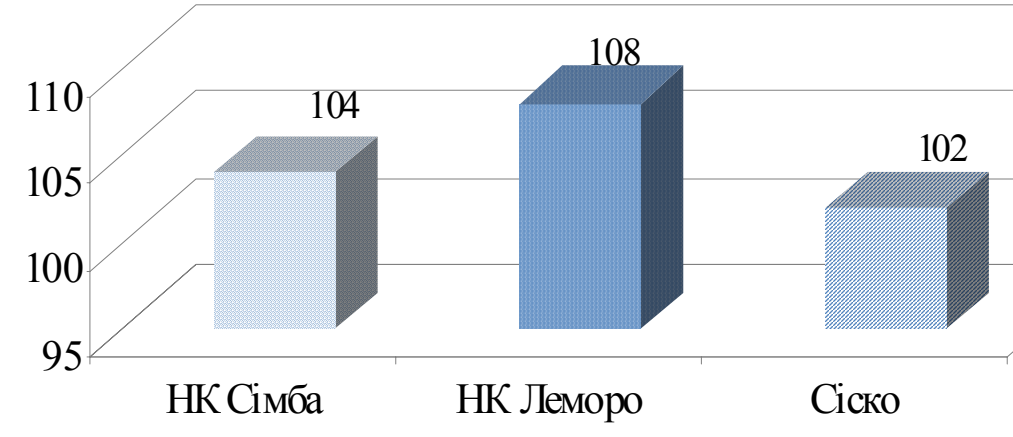

Рис. 1. Кількість качанів на 100 рослинах, шт. 


\section{СІЛЬСЬКЕ ГОСПОДАРСТВО. РОСЛИННИЦТВО}

На показники маси зерна 3 одного качана впливали фактори, що вивчались та гідротермічний режим. Встановлено, що найбільші за масою качани формував гібрид НК Леморо - 184 г. На 3,9 \% нижче цей показник був у гібрида НК Сімба та на 3,2 \% у Сіско.

Важливим показником також є маса 1000 зерен. Результати досліджень показали, що вона залежала від погодних умов у період вегетації та морфобіологічних особливостей гібридів. Найбільшу масу тисячі зерен формував середньостиглий гібрид НК Леморо - 306 г. На 4 г легшим виявилася маса тисячі зерен середньопізнього гібрида
Сіско та на 17 г - середньораннього гібрида НК Сімба.

Дослідження, які проводили, показали, що у 2014-2015 рр. урожайність зерна різних біотипів кукурудзи залежала певною мірою від погодних умов періоду вегетації рослин та біологічного потенціалу гібридів. У ранньостиглих гібридів вона менша, ніж у середньостиглих і середньопізніх. Однак ранньостиглі гібриди раніше достигають i, як правило, їх зерно не потребує післязбирального сушіння, що зменшує вартість їх виробництва.

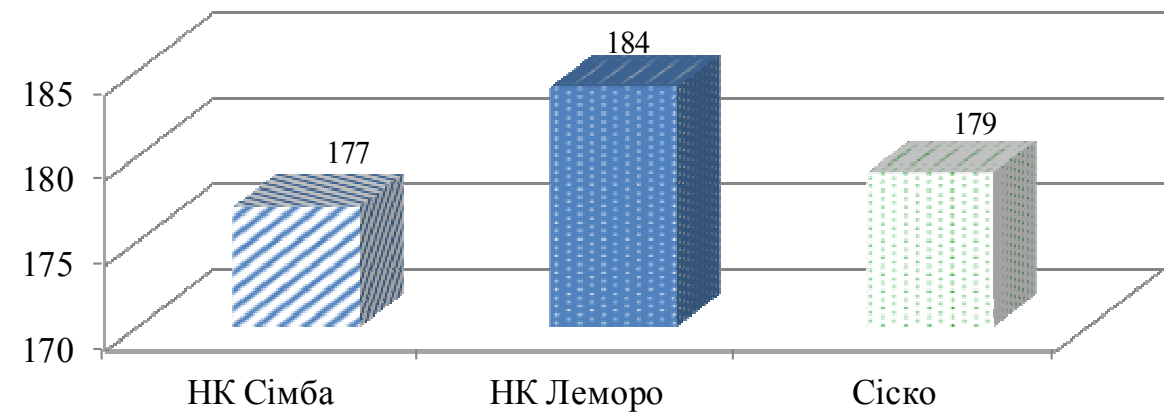

Pис. 2. Маса зерна з одного качана, 2

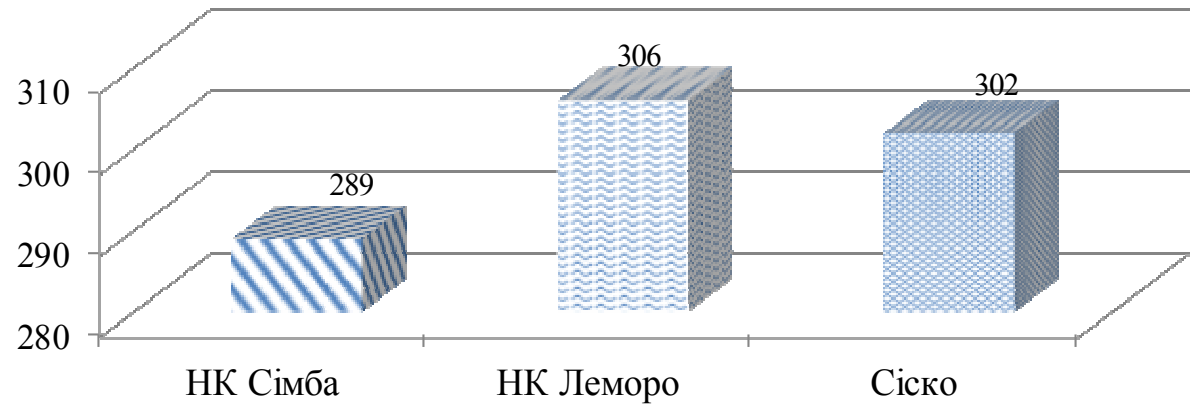

Рис. 3. Маса тисячі зерен, 2

2. Урожайність, вологість зерна та ефективність вирощування гібридів кукурудзи

\begin{tabular}{|c|c|c|c|c|c|c|c|}
\hline \multirow{2}{*}{ Гібрид } & \multirow{2}{*}{$\begin{array}{c}\text { Урожай- } \\
\text { ність, т/га (за } \\
14 \text { \% волого- } \\
\text { сті) }\end{array}$} & \multirow{2}{*}{$\begin{array}{c}\text { Вологість } \\
\text { зерна, } \\
\text { \% }\end{array}$} & \multicolumn{2}{|c|}{$\begin{array}{c}\text { Виробничі } \\
\text { витрати, грн/га }\end{array}$} & \multirow{2}{*}{$\begin{array}{c}\text { Собівар- } \\
\text { тість } \\
\text { зерна, грн/т }\end{array}$} & \multirow{2}{*}{$\begin{array}{c}\text { Умовно } \\
\text { чистий } \\
\text { прибуток, } \\
\text { грн }\end{array}$} & \multirow{2}{*}{$\begin{array}{c}\text { Рента- } \\
\text { бель- } \\
\text { ність, } \\
\text { \% }\end{array}$} \\
\hline & & & всього & на сушіння & & & \\
\hline НК Сімба & 8,03 & 16,4 & 11045 & 1687 & 1375 & 19272 & 174 \\
\hline НК Леморо & 8,67 & 17,2 & 11368 & 1769 & 1311 & 20808 & 183 \\
\hline Сіско & 7,97 & 19,1 & 10986 & 1964 & 1378 & 19128 & 174 \\
\hline
\end{tabular}


Отже, оптимальне поєднання елементів структури дає можливість отримати максимально високий врожай зерна кукурудзи. Найбільш адаптованим для даних умов вирощування виявився середньостиглий гібрид НК Леморо, що сформував урожайність 8,67 т/га зерна.

Дещо нижчу врожайність було отримано у випадку вирощування середньораннього гібрида НК Сімба - 8,03 т/га та середньопізнього Сіско 7,97 т/га.

Розрахунки економічної ефективності вирощування кукурудзи показали, що на рівень рентабельності виробництва зерна впливала як урожайність цих гібридів, так і в певній мірі його вологість (табл. 2).

Найбільші виробничі затрати відмічено під час вирощування гібридів 3 високою передзбиральною вологістю зерна, яке потребувало збі-

\section{БІБЛІОГРАФІЯ}

1. Циков В. С. Кукуруза: технология, гибриды, семена. - Днепропетровск : Зоря, 2003. - 296 с.

2. Циков В. С. Прогрессивная технология выращивания кукурузы. - К. : Урожай, 1984. - 192 с.

3. Ткаліч Ю. I. Оптимізація площі живлення основа високих урожаїв кукурудзи // Хранение и переработка зерна. - Днепропетровск, 2002. №3 (33). - С. 27-29.

4. Андрієнко А. Л. Основні заходи сортової агротехніки гібридів кукурудзи різних груп стиг- льшення витрат для доведення його до стандартних кондицій (вологість 14 \%).

Результати досліджень свідчать, що виробничі витрати були дещо більшими під час вирощування середньостиглого гібрида порівняно 3 середньораннім та середньопізнім.

Це обумовлено більшою врожайністю зерна кукурудзи та збільшенням затрат під час збирання i післязбиральній доробці зерна. Але в результаті показники собівартості, чистого прибутку та рівня рентабельності у гібрида НК Леморо сформувались вищими за рахунок прибавки врожаю.

Висновок. Для отримання високих врожаїв та показників економічної ефективності в умовах господарства рекомендовано для вирощування гібрид НК Леморо.

лості в північному Степу України : автореф. дис. ... к.с.-Г.н. - Дніпропетровськ, 2004. - 19 с.

5. Кирсанова Г. В. Формування фотосинтетичного потенціалу рослин різних гібридів кукурудзи залежно від умов вирощування / Г. В. Кирсанова, М. В. Котченко, Д. В. Ковальов // Materials of XI international research and practice conference «Scientific horizons - 2015». - Vol. 9. P. 81-82. 